\title{
Jurist-Diction
}

Volume 2 No. 5 September 2019

Histori artikel: Submit 28 Juli 2019; Diterima 23 Agustus 2019; Diterbitkan online 1 September 2019.

\section{Proses Pemeriksaan Perjudian sebagai Tindak Pidana Kesusilaan}

\author{
Renda Aranggraeni \\ rendaaini15@gmail.com \\ Universitas Airlangga
}

\begin{abstract}
National law explicitly states that the State of Indonesia is a state of law, the definition of the rule of law actually implies that a country adheres to the teachings and principles of the supremacy of the law in which the law is upheld as a guideline and determinant of the direction of policy in carrying out the principles of the life of the nation and state. The provisions relating to the gambling inspection process should be in accordance with national legal provisions regarding the inspection process which must be open to the public unless the case concerns the decency and the accused of the child. However, with the fact that the application of the gambling examination process is a criminal act of decency, the majority at the level of investigation, investigation and court is a process of examination that is open to the public. Regarding this matter, it is certainly very contrary to the principles of national law so that if it is not in accordance with the theory or principles and principles that have been determined regarding the process of gambling examination, it will certainly result in null and void law. There is no exception to the right of judges or law enforcers to carry out a discretion by overriding existing legislation. By appealing to these legal problems, for this reason there is a need for a goal where judges or law enforcers understand and understand the meaning of the application of national law that gambling is a qualification for crime against decency.

Keywords: Decency; Gambling; Cancel For Law; Examination Process; Discretion.
\end{abstract}

\begin{abstract}
Abstrak
Pasal 1 ayat (3) UUD 1945 (hasil amandemen) menyebutkan secara tegas bahwa Negara Indonesia adalah negara hukum, pengertian negara hukum sesungguhnya mengandung makna bahwa suatu negara menganut ajaran dan prinsip-prinsip tentang supremasi hukum di mana hukum dijunjung tinggi sebagai pedoman dan penentu arah kebijakan dalam menjalankan prinsip kehidupan berbangsa dan bernegara. Pada ketentuan terkait dengan proses pemeriksaan perjudian yang terdapat dalam Bab XIV Kejahatan terhadap Kesusilaan, khususnya pasal 303 KUHP, maka sudah seharusnya sesuai dengan ketentuan Pasal 153 KUHAP ayat (3) mengenai proses pemeriksaan wajib terbuka untuk umum kecuali jika perkara kesusilaan dan terdakwanya anak-anak. Namun, dengan adanya fakta mengenai penerapan proses pemeriksaan perjudian sebagai tindak pidana kesusilaan, mayoritas pada tingkat penyidikan, penyelidikan maupun pengadilan yaitu proses pemeriksaan yang terbuka untuk umum. Mengenai hal tersebut, tentu sangat bertentangan dengan prinsip bunyi Pasal 153 KUHAP ayat (3), dan jika tidak sesuai dengan teori ataupun prinsip dan asas yang telah ditentukan mengenai proses pemeriksaan perjudian tentu akan berakibat batal demi hukum. Tidak adanya pengecualian adanya hak para hakim ataupun penegak hukum untuk melakukan suatu diskresi dengan mengesampingkan peraturan perundang-undangan yang ada. Dengan menarik adanya masalah hukum tersebut, untuk itu perlu adanya suatu tujuan di mana, para hakim ataupun penegak hukum memahami dan mengerti makna dari adanya penerapan Pasal 303 KUHP bahwasannya perjudian merupakan kualifikasi kejahatan terhadap kesusilaan.
\end{abstract}

Kata Kunci: Kesusilaan; Perjudian; Batal Demi Hukum; Proses Pemeriksaan; Diskresi. 


\section{Pendahuluan}

Indonesia adalah salah satu negara berkembang (developing country) dengan berbagai latar belakang setiap individu negaranya. ${ }^{1}$ Dengan keadaan perekonomian masyarakat khususnya negara berkembang seperti Indonesia berimplikasi terhadap rendahnya pendapatan masyarakat serta banyaknya masyarakat yang tidak bekerja menjadikan masyarakat rural maupun masyarakat urban khususnya yang tidak mengeyam pendidikan demi mendapatkan penghasilan berlebih, mereka memilih melakukan segala cara untuk dapat memenuhi kebutuhan hidup. Inilah yang memicu mereka menghalalkan segala cara ataupun melegalkan segala hal yang bertentangan dengan hukum.

Menurut anggapan mereka meski nantinya harus berhadapan dengan hukum ataupun pengadilan yang terpenting menurut mereka hal tersebut memiliki keuntungan materiil bagi mereka. Salah satu hal yang bertentangan dengan hukum, namun kerap dilakukan oleh masyarakat tersebut adalah perjudian. ${ }^{2}$ Dengan adanya iming-iming keuntungan, salah satu cara mudah mendapatkan penghasilan secara cepat yakni melegalkan perjudian dengan harapan menemukan kemenangan dan penghasilan secara cepat, tanpa bekerja keras, karena hanya mengandalkan sebuah permainan kartu belaka. Persepsi terhadap judi telah dirumuskan dalam Pasal 303 ayat (3). Unsur utama dari judi adalah "untung-untungan" beberapa ahli pakar Sosiologi Hukum juga menyebut "tergantung nasib", terhadap pertaruhan dirumuskan : Semua pertaruhan yang tidak dilakukan antara mereka yang turut serta bermain, misalnya : A dan B mengadakan pertaruhan Rp. 10.000,- untuk berlomba lari dalam jarak 100 meter.

Pertaruhan antara A dengan B tidak dapat dihukum. Lain halnya jika R dengan S melakukan pertaruhan tentang perlombaan A dengan B tersebut. ${ }^{3}$ Wirjono Prodjodikoro berpendapat dalam bukunya yakni "Tindak Pidana Tertentu di

\footnotetext{
1 Fitroh Rohcahyanto, Memperdagangkan Pengaruh (Trading In Influence) Sebagai Tindak Pidana Korupsi (Universitas Airlangga 2018).[3].

2 ibid.[81].

3 ibid.[83].
} 
Indonesia", hakekatnya perjudian merupakan tindak kejahatan terhadap kesusilaan, dan kesusilaan itu dipengaruhi oleh agama, kebudayaan adat istiadat sebagaimana yang terdapat dalam masyarakat dan khususnya sedikit banyak mengenai kelamin (sex) seseorang. Kegiatan perjudian sendiri dapat merusak moral manusia dan merugikan masyarakat karena dengan cara pertaruhan sejumlah uang dan/atau barang berharga yang di dalamnya berdasarkan suatu kebetulan dan tergantung nasib untung-untungan semata.

Aktivitas perjudian sudah lama ada, kebudayaan satu ini sudah turun temurun menjadi satu kebudayaan yang dianggap tidak tabu lagi oleh sebagian masyarakat kita ini, bukan hanya perilaku sesaat, melainkan telah menjadi bagian dari mental kehidupan dirinya sendiri. Ketika mental judi menguat, jangankan nomor matematika, peristiwa-peristiwa keseharian pun diperjudikan. ${ }^{4}$ Dalam pertimbangan Undang-Undang Penertiban Perjudian juga jelas tersirat kalimat yang menyatakan bahwa perjudian bertentangan dengan kesusilaan.

Mengingat pula bahwasannya perjudian adalah salah satu penyakit masyarakat yang menunggal dengan kejahatan, yang identik dengan foya-foya. Menurut tulisan-tulisan yang ada, judi sudah ada sejak 3500 Sebelum Masehi (SM) yaitu pada jaman Jahiliyah. Pada jaman tersebut dikenal 2 (dua) bentuk Al-Maisir (Judi), yaitu Al-Mukhtarah dan Al-Tajziah. Dalam Al-Mukhtarah, dua laki-laki atau lebih menempatkan harta atau istri mereka sebagai taruhan dalam suatu permainan. Pelaku dan/atau pemain yang berhasil memenangkan permainan itu yakni perjudian berhak mengambil harta atau istri pelaku dan/atau pemain yang kalah. Jika ia suka, ia dapat mengawininya atau bahkan dijadikannya budak seksualitas.

Sedangkan Al-Tajziah lebih kepada hewan peliharaan, yang pada jaman itu berupa unta untuk dipotong dan dagingnya disumbangkan. ${ }^{5}$ Pengaturan masalah kesusilaan terdapat pada Buku II Bab XIV Tentang Kejahatan tehadap Kesusilaan Pasal 281-303 dan terdapat pula pada Buku III Bab VI Tentang Pelanggaran

4 Hendik Bagus Sudiharto, Praktik Perjudian Legal Terselubung Di Indonesia Menurut Peraturan Perundang-Undangan Yang Berlaku (Universitas Airlangga 2005).[1].

5 ibid.[2]. 
Kesusilaan Pasal 532-547, yaitu perjudian masuk pada kategori Pasal 303 ayat (3) Ketentuan Kitab Undang-undang Hukum Pidana (KUHP), Dimasukkannya perjudian dalam Bab XIV tentang Kejahatan terhadap Kesusilaan, maka hal ini menjelaskan mengenai pengertian tindak pidana kesusilaan sangat luas, universal dan tidak hanya meliputi aspek moral serta tindakan asusila, namun juga dari segi agama dan kesopanan. Dalam pengertian sempit untuk jenis kejahatan kesusilaan meliputi: pornografi; perzinahan; perkosaan; pencabulan; pengguguran kandungan; pelacuran; serta tindakan yang berkaitan dengan kejahatan asusila. ${ }^{6}$

Hal ini, berarti untuk tindak pidana perjudian sebagai kejahatan terhadap kesusilaan telah mengalami pergeseran pemahaman tentang tindak pidana kesusilaan. ${ }^{7}$ Penggunaan istilah tindak pidana, dari pandangan para pakar memang belum ada keseragaman. Ada yang menggunakan istilah Perbuatan Pidana, Tindak Pidana, Peristiwa Pidana, Perbuatan Kriminil atau Delik (delict). Menurut Didik Endro Purwoleksono, penggunaan istilah tindak pidana sudah tepat dengan beberapa alasan yang dapat dijelaskan, yaitu kesemua dari beberapa undangundang sudah menerapkan istilah dengan penggunaan kalimat "Tindak Pidana" sebagai misal yakni Undang-undang Pemberantasan Tindak Pidana Korupsi, Undang-undang Tindak Pidana Terorisme, Undang-undang Pemberantasan Tindak Pidana Perdagangan Orang (UU TPPO), Undang-undang Kesehatan juga secara tegas dalam Pasal 85 menyebut dengan penggunaan kalimat tindak pidana. ${ }^{8}$

Code penal Perancis maupun di Belanda tetaplah sama dalam hal melakukan pembatasan yang ketat terhadap delik-delik kesusilaan, karena tidaklah semua hal yang termasuk perbuatan tercela menurut norma-norma susila dapat dikualifisir begitu saja sebagai suatu tindak pidana. Undang-Undang hanya dapat ikut campur dalam menciptakan delik-delik susila apabila perbuatan asusila itu berkaitan dengan aandgerand atau openlijk beledigd. Dengan demikian, menurut Barda, sejatinya

\footnotetext{
6 Toetik Rahayuningsih, 'Kejahatan Kesusilaan Dan Upaya Penanganannya (Studi Pada Tingkat Penyidikan, Penuntutan, Dan Pemeriksaan Pengadilan Surabaya)', 31 Jurnal Universitas Airlangga [2]

7 ibid.

8 Didik Endro Purwoleksono, Hukum Pidana (Airlangga University Press 2014) [43]
} 
tidaklah mudah dalam hal menetapkan batas-batas dan/atau ruang lingkup delik kesusilaan, karena pengertian dan batas-batas "kesusilaan" itu cukup luas dan berbeda-beda menurut pandangan dan nilai yang berlaku dalam masyarakat.

Terlebih karena hukum itu sendiri hakekatnya merupakan nlai-nilai kesusilaan yang minimal das recht das ethische minimum. ${ }^{9}$ Dalam lokakarya mengenai "BabBab Kodifikasi Hukum Pidana (Buku II), yang diselenggarakan oleh BPHN Departemen Kehakiman pada tanggal 23-25 April 1985 di Jakarta, masalah ini pernah dibahas dalam makalah Roeslan Saleh. Makalah tersebut, dikemukakan bahwa "pengertian dari kesusilaan seyogyanya tidak dibatasi mengenai pengertian kesusilaan dalam bidang seksual saja, tetapi juga meliputi hal-hal lain yang termasuk dalam penguasaan norma-norma kepatutan bertingkah laku dalam pergaulan masyarakat. Karena terkait tindak pidana kesusilaan lazimnya menimbulkan banyak kekhawatiran atau kecemasan masyarakat terhadap suatu tindakan yang merugikan orang lain tanpa diketahui efek secara nyata namun ada, hal ini pula menjadi salah satu tantangan bagi penulisan skripsi ini untuk dapat memecahkan delik kesusilaan pada tindak pidana perjudian, pun terhadap delik ini sering kali menjadikan banyak salah penafsiran bahkan sering juga menimbulkan kesulitan dalam hal penyelesaiannya, baik pada tahap penyidikan, penuntutan maupun pada tahap pengambilan keputusan. ${ }^{10}$

Berkaitan pula dengan beragam jenis perjudian di kalangan masyarakat, untuk itu dibutuhkan sikap tegas guna menanggulanginya, karena dirasa sudah semakin tidak kondusif lagi kegiatan perjudian dengan dijadikannya sebagai mata pencaharian juga sebagai perilaku menyimpang. Hal ini sangatlah beralasan karena perjudian pada umumnya masuk dalam kategori kejahatan terhadap kesusilaan yang deliknya menimbulkan kekhawatiran atau kecemasan masyarakat sekitar,

\footnotetext{
9 Eman Sulaeman, Delik Perzinaan Dalam Pembaharuan Hukum Pidana di Indonesia, (Walisongo Press 2008).[85].

10 Ungkapan serupa dikatakan oleh George Jelinek bahwa "the law as an ethical minimum" (Stephen Aschafer, The political Criminal, 1973: 67). Juga terlihat dalam ungkapanAlfred Denning, bahwa "without religion there can be no morality and without morality there can be no", (Oemar Senoadji, Mass Media \& Hukum, 1977).[141].
} 
serta menjadi ancaman riil atau potensiil bagi pertumbuhan perekonomian dan bagi keberlangsungan ketertiban sosial. ${ }^{11}$ Dengan dimasukkannya perjudian sebagai tindak kejahatan terhadap kesusilaan, maka perkara perjudian dalam proses pemeriksaan harus mengacu pada ketentuan Pasal 153 ayat (3) KUHAP. ${ }^{12}$

\section{Metode Penelitian}

Penelitian ini merupakan penelitian hukum normatif yang menggunakan tiga pendekatan, yaitu, pendekatan perundang-undangan (statute approach), pendekatan kasus (case approach), dan pendekatan konseptual (conceptual approach), ${ }^{13}$ yang akan sedikit diuraikan sebagai berikut:

1. Pendekatan perundang-undangan meliputi penelusuran terhadap naskah komprehensif Undang-Undang Nomor 1 Tahun 1946 yaitu KUHP jo Undang-

Undang Nomor 8 Tahun 1981 yakni KUHAP, khususnya pada Pasal 303 KUHP bahwa masuk dalam delik kesusilaan dan penelusuran terhadap KUHAP khususnya pada Pasal 153 ayat 3 untuk menelaah ratio decidendi sebuah putusan dari perjudian.

2. Pendekatan kasus akan merujuk pada kasus perjudian yaitu sebuah putusan pengadilan yang banyak dilakukan mengenai proses pemeriksaan perjudian secara terbuka.

3. Pendekatan konseptual akan mengkaji beberapa doktrin-doktrin tentang konsep kesusilaan serta memorie van toelichting (MvT) dari adanya ketentuan Pasal 303 KUHP untuk mendapat konsep yang tepat.

11 ibid.[21].

12 Lihat KUHP, Pasal 303 menyebutkan "Yang disebut permainan judi adalah tiap-tiap permainan, di mana pada umumnya kemungkinan mendapat untung bergantung pada peruntungan belaka, juga karena pemainnya lebih terlatih atau lebih mahir. Di situ termasuk segala pertaruhan tentang keputusan perlombaan atau permainan lain-lainnya, yang tidak diadakan antara mereka yang turut berlomba atau bermain, demikian juga segala pertaruhan lainnya."

13 Peter Mahmud Marzuki, Penelitian Hukum Edisi Revisi (Prenadamedia Group 2016). $[133-136]$. 


\section{Proses Pemeriksaan Tindak Pidana Perjudian yang Dimasukkan dalam Buku}

\section{Bab XIV KUHP tentang Kejahatan terhadap Kesusilaan}

1. Konsep Kesusilaan

Kata "Kesusilaan” dalam KBBI yakni Kamus Besar Bahasa Indonesia yang disusun oleh Departemen Pendidikan dan Kebudayaan, diterbitkan Balai Pustaka 1989, dimuat artinya "perihal susila" kata "susila" dimuat arti sebagai berikut:

1. Baik budi bahasanya, beradab, sopan, tertib;

2. Adat istiadat yang baik, sopan santun, kesopanan, keadaban.

3. Pengetahuan tentang adat.

Kata susila yang di dalam bahasa Inggris yaitu sebuah moral, ethics, decent. Kata-kata tersebut lazimnya diterjemahkan berbeda. Kata moral diterjemahkan dengan moril, kesopanan, sedang ethics diterjemahkan dengan kesusilaan dan decent diterjemahkan dengan kepatutan. Terdapat kata yang dianggap rumit dan selalu sulit ditafsirkan bahkan dikombinasikan adalah "moral" dan "ethics". Kedua kata tersebut mengandung decent. Namun, jika diamati dengan cermat, ternyata ethics lebih sempit daripada moral, tetapi ethics ada dalam kata moral. ${ }^{14}$

Dalam hal dikatakan kejahatan terhadap kesusilaan, ketentuan pidana yang mengatur di dalam Bab XIV dari buku ke-II KUHP, dalam kaitannya pada Wetboek van Strafrecht juga disebut sebagai Misdrijven tegen de zeden yang artinya kejahatan terhadap moral. pada umumnya menimbulkan kekhawatiran dan/atau rasa cemas khususnya orang tua terhadap anak wanita karena faktor selain dapat mengancam keselamatan anak-anak wanita (misalnya : perkosaan, perbutan cabul) dapat pula mempengaruhi proses tumbuh kembang ke arah kedewasaan seksual lebih dini. Delik ini paling dominan memicu untuk timbulnya kesulitan dalam penyelesaiannya di tingkat pada tahap penyidikan, penuntutan maupun pada tahap pengambilan keputusan. Selain kesulitan dalam batasan juga kesulitan pembuktian misalnya perkosaan ataupun perbuatan cabul yang pada umumnya dilakukan tanpa kehadiran orang lain. ${ }^{15}$

14 Leden Marpaung, Kejahatan Terhadap Kesusilaan Dan Masalah Prevensinya (Sinar Grafika 1996).[81].

15 ibid.[30]. 
Terhadap tindak pidana "merusak kesusilaan", Mr. J.M. Van Bemmelen menyampaikan antara lain : "tentang delik mengenai kesusilaan sejatinya tidak hanya memuat berbagai kejahatan seksual, akan tetapi juga terdapat beberapa delik yang sama sekali tidak terdapat korelasi ataupun sangkut pautnya dengan seksualitas; memberi minuman yang dapat memicu timbulnya akibat memabukkan kepada orang atau anak-anak di bawah usia enam belas tahun yang sudah kelihatan mabuk. ${ }^{16}$

Pelanggaran suatu kehormatan kesusilaan di muka umum ialah terjemahan dari "outrage public a la pudeur" dalam Pasal 330 Code Penal. Ini dapat ditafsirkan sebagai "tidak ada kesopanan di bidang seksual". Jadi terhadap kesimpulan makna sopan ialah tindakan atau tingkah laku untuk apa seseorang tidak memikirkan rasa malu apabila orang lain melihatnya atau sampai dengan mengetahuinya dan juga oleh karena orang lain itu pada umumnya tidak akan terperanjat apabila melihat atau bahkan sampai mengetahuinya. ${ }^{17}$ Pengertian “di muka umum” menurut Mr. J.M. van Bemmelen adalah sebagai berikut "di muka umum menurut pandangan saya ialah apa yang terjadi di tempat terbuka atau dapat dilihat dari tempat terbuka." Pendapat Mr. J.M. van Bemmelen tersebut telah berkaitan dengan Arres Hoge Raad (HR) tanggal 12 Mei 1902 yakni antara lain memuat bahwasannya melanggar kesusilaan di muka umum meliputi atas perbuatan yang dilakukan di tempat umum dan/atau di tempat yang dapat di lihat dari tempat umum, meskipun dilakukan di tempat yang bukan tempat umum. ${ }^{18}$ Maka dalam kaitannya tindak pidana perjudian sudah sangatlah tepat dimasukkan dalam kejahatan kesusilaan, khususnya juga perjudian yang dilakukan di tempat umum seperti pasar, taman atau kawasan sekolah. Delikdelik susila sewaktu Prof. Van Bemmelen mengadakan pemilihan pembagian dari delik-delik khusus, maka delik-delik susila dipandang memegang posisi tengah antara delik-delik terhadap jiwa dan badan, yang sangat spektakuler dan delik-delik terhadap harta benda yang frekwen. Jika kita hendak berbicara tentang delik-delik susila, mungkin pula mengenai delik-delik lain, maka rangkuman dalam KUHP

\footnotetext{
16 ibid.

17 J.M. van Bemmelen, Hukum Pidana Jilid I,II,III (Bina Cipta 1986).[23].

18 ibid.
} 
yang kita ikuti, mungkin menggambarkan garis yang berlainan dalam system di negara-negara Common Law, yang juga mengaturnya masalah perkembanganperkembangan tentang delik-delik susila itu daam beberapa perundang-undangan dan tidak mencakup itu dalam sebuah kodifikasi. ${ }^{19}$

Sering dikatakan, bahwa salah satu perbedaan antara Hukum Kontinental yang tampaknya berpengaruh pula terhadap Hukum Aglo Saxon terdapat dalam kenyataan, bahwa adanya kodifikasi dalam negara-negara Kontinental Eropa, sedangkan kodifikasi itu tidak demikian dikenal di Hukum Aglo Saxon. Maka, dalam KUHP delik-delik susila diatur dalam Bab tersendiri, ialah "Kejahatan Terhadap Kesusilaan", sedangkan pengaturan tentang delik-delik susila itu terdapat dalam beberapa undang-undang di negara-negara Common Law. Oleh karena itu disebutkan Prof. Brian Hogan, sewaktu ia menulis tentang "On modernizing the Law of Sexual Offences" bahwa hukum yang ada mengenai delik-delik susila (sexual offences) sebagian besar termuat dalam "Sexual Offences Act 1956", dengan tambahan dan modifikasi dari "Street Offences Act 1959”, "Indecency with Children Act 1960", "Sexual Offences Act 1967", dan "Sexual Offences (Amandment) Act 1976". ${ }^{20}$ Untuk itu, penting memahami makna dari kesusilaan itu sendiri. Delik kesusilaan merupakan delik yang berhubungan dengan masalah kesusilaan. Definisi yang singkat dan sederhana itu apabila dikaji lebih lanjut untuk mengetahui seberapa jauh ruang lingkupnya ternyata tidaklah mudah, karena pengertian dan batas-batas "kesusilaan" itu cukup luas dan dapat berbeda-beda menurut pandangan dan nilai yang berlaku di dalam masyarakat. ${ }^{21}$ Tindak pidana perjudian, perjudian juga merupakan penyakit masyarakat yang pada norma intinya bertentangan dengan Agama, Kesusilaan, dan Moral Pancasila, serta membahayakan bagi penghidupan dan kehidupan masyarakat, Bangsa dan Negara. Oleh karena itu Pemerintah Indonesia mengadakan usaha-usaha untuk menertibkan perjudian, membatasinya

\footnotetext{
${ }^{19}$ Oemar Seno Adji, Herziening Ganti Rugi Suap Perkembagan Delik (Erlangga 1984).[266].

20 ibid.[267].

${ }^{21}$ Sri Hartini, 'Perbuatan Pidana Kesusilaan Dalam Rancangan Undang-Undang KUHP'
} (2004) 2 Jurnal Civics.[216-217]. 
sampai lingkungan sekecil-kecilnya, untuk akhirnya menuju ke penghapusan sama sekali dari seluruh wilayah Indonesia. ${ }^{22}$

Dimasukkannya tindak pidana seperti yang dimaksudkan di dalam ketentuan pidana yang diatur Pasal 303 KUHP ke dalam pengertian tindak pidana terhadap kesusilaan, menunjukkan sulitnya orang memasukkan tindak pidana tersebut ke dalam pengertian tindak pidana manapun, yang diatur di dalam KUHP. Menurut Prof. van Bemmelen dan Prof. van Hattum, ditelaah dari sejarahnya, penempatan tindak pidana yang dimaksudkan di dalam ketentuan pidana yang diatur Pasal 303 KUHP sebagai suatu tindak pidana terhadap kesusilaan sudahlah tepat. Tentang hal tersebut, berkatalah Prof. van Bemmelen dan Prof. van Hattum yakni:

"Historich bezien is duidelijk, dat strafwaardigheid hier berust op het feit, dat door het spel en wel in het bijzonder, die de zelffbeheersing in gevaar bregen en die op derden zo wel afstotend als aantrekkend kunnen werken. De spanningen van het spel nemen remmingen weg, ook ten opzichte van andere ondeugden dan het spel zelf. Zo is er altijd verband gezien tussen spel en drankmisbruik en prostitutie.

Artinya :

Ditinjau dari sejarahnya sudahlah jelas,bahwa yang merupakan dasar bagi dapat dipidananya perbuatan ini terletak pada kenyataan yakni bahwa oleh permainan untung-untungan, hasrat orang menjadi tidak dapat dikendalikan dan dapat menimbulkan bahaya bagi penguasaan diri, dan bagi pihak ketiga dapat mempunyai pengaruh, baik yang bersifat menolak maupun yang bersifat menarik. Pengaruh permainan ini dapat meniadakan penilaian yang tidak baik dari orang terhadap perbuatan-perbuatan tidak baik lainnya, yang lebih tidak baik dari permainannya itu sendiri, yakni karena orang selalu melihat adanya hubungan antara perjudian, penyalahgunaan minuman keras dan pelacuran". ${ }^{23}$

Menurut Prof. van Bemmelen dan Prof. van Hattum, perjudian membuat asas loon naar arbeid atau asas mendapat penghasilan karena berkarya menjadi tidak dapat dilaksanakannya dengan sebaik-baiknya, karena dibangkitkannya harapan orang untuk cepat menjadi kaya tanpa bekerja. Pembangkitan harapan seperti itu adalah keliru dan demi kebaikan masyarakat, perbuatan seperti itu perlu dihentikan. Asas

${ }^{22}$ Soka Adista Fajar Wirawan, Pelaksanaan Persidangan Dalam Kasus Tindak Pidana Kesusilaan Terkait Dengan Penerapan Ketentuan Pasal 282 KUHP dan Pasal 153 ayat 3 KUHAP (Departemen Pendidikan Nasional Universitas Brawijaya 2007).[14].

${ }^{23}$ Wirjono Prodjodikoro, Tindak-Tindak Pidana Tertentu Di Indonesia (Refika Aditama 2010).[268]. 
terkait dengan pemeriksaan pengadilan terbuka untuk umum, asas ini telah dikenal sejak dikeluarkannya UUDS Tahun 1950 dan yang tepatnya diatur dalam Pasal 104 ayat (2) dan ayat (3), asas ini juga terdapat di dalam Pasal 17 ayat (1) UU Nomor 14 Tahun 1970 Tentang Ketentuan-Ketentuan Pokok Kekuasaan Kehakiman yang menentukan bahwa sidang pemeriksaan pengadilan terbuka untuk umum kecuali apabila undang-undang menentukan lain. Pada ayat (2) nya menentukan bahwa apabila tidak dipenuhi kekuatan hukum dalam ayat (1) nya mengakibatkan batalnya putusan menurut hukum. Selanjutnya, dalam Pasal 18 juga ditentukan bahwa "Semua putusan pengadilan hanya sah dan mempunyai kekuatan hukum apabila diucapkan dalam sidang terbuka untuk umum”.

\section{Akibat hukum terhadap putusan tindak pidana perjudian sebagai kejahatan kesusilaan}

Akibat hukum adalah suatu akibat yang ditimbulkan oleh hukum, terhadap suatu perbuatan yang dilakukan oleh subyek hukum. Akibat yang dimaksud adalah akibat yang diatur oleh hukum, sedangkan tindakan yang dilakukan merupakan tindakan hukum yaitu tindakan yang sesuai dengan hukum yang berlaku. Berkaitan dengan kasus tindak pidana perjudian, untukjenis perkara pada tingkat pertama, yakni Pengadilan Negeri, majelis hakim pada tingkat pengadilan negeri dalam putusannya lebih banyak menggunakan sistem proses pemeriksaan secara terbuka, dari hal tersebut muncul sebuah pemikiran adanya bentuk diskresi hakim yang dimaknai hakim sedang menjalankan proses pembentukan undang-undang sebagaimana tugas dan kewenangan seorang legislator, dalam kaitannya suatu undang-undang tidak dapat memberikan keadilan dan justru menimbulkan ketidakadilan, maka hakim harus berani mengambil sikap untuk menyimpanginya. Dari hal tersebut, para hakim maupun penuntut umum atau bahkan penasehat hukum khususnya yang menangani kasus tindak pidana perjudian telah mengabaikan ketentuan Pasal 153 ayat (3) KUHAP yang menyatakan : Untuk keperluan pemeriksaan hakim ketua sidang membuka sidang dan menyatakan terbuka untuk umum kecuali dalam perkara mengenai kesusilaan atau terdakwanya anak-anak. 
Karena dalam ketentuan Pasal 303 KUHP, mengenai tindak pidana perjudian telah masuk dalam Bab Kejahatan terhadap Kesusilaan, tidak adanya pengecualian dalam ketentuan pasal tersebut, bahwasannya menurut KUHAP, haruslah tertutup untuk umum, karena berdasarkan atas apa yang dijelaskan sebelumnya, yakni kejahatan terhadap kesusilaan yang terdapat suatu aspek daripada moral guna memuat anasiranasir seks seorang manusia sebagaimana dikatakan oleh Prof. Wiryono Prodjodikoro dalam bukunya "Tindak-tindak Pidana tertentu di Indonesia", cetakan 1967 hal 116 : "kesusilaan mengenai juga adat kebiasaan yang baik itu, tetapi khususnya yang sedikit banyak mengenai kelamin (sex) seorang manusia”. Disamping aspek kesusilaan moral itu meliputi juga aspek-aspek lain, yaitu agama dan adat. Agama menentukan norma-norma yang harus ditaati oleh seluruh umatnya, sedangkan adat menimbulkan norma-norma harus diikuti oleh seluruh masyarakat adat itu. Aspek-aspek itu saling mempengaruhi satu sama lain, hingga norma-norma kesusilaan agama dan adat satu sama lain tidak dapat dibedakan lagi. Hal ini tampak dalam semua kejahatan terhadap kesusilaan dalam Bab XIV Buku II KUHP.

Seringkali masyarakat dihadapkan tentang tindakan-tindakan penyelesaian hukum oleh pengadilan yang dipandang sebagai suatu perlakuan ketidaksamaan antara mereka yang mencari keadilan. Dilihat secara umum, dikatakan bahwa dalam bidang peradilan dapat dibedakan tiga tingkat yang sifat ketidaksamaan itu pada prinsipnya dapat terjadi. Pertama dalam bidang perundang-undangan, kedua dalam bidang proses penyelesaian menurut undang-undang, dan ketiga dalam bidang penyelesaian perkara masing-masing. Berkaitan dengan hal itu, timbul suatu diskresi pada hakim, yang terhadap tugas, pokok dan fungsinya sebagai pemutus perkara, memiliki kebebasan untuk dapat mengadakan berbagai variasi dalam pidananya tentu saja dalam batas-batas yang telah ditentukan oleh undangundang, merupakan segi positif dari kebebasan bergerak dan dalam penerapan hukum pidana. Tetapi, juga ada suatu sisi yang lain. Kebebasan itu membiarkan pula pada prinsipnya kemungkinan terjadinya ketidaksamaan hukum. Sadar atau tidak sadar pandangan-pandangan pribadi dari pejabat-pejabat yang bersangkutan akan mempengaruhi keputusan-keputusannya. 
Telah dijelaskan terhadap adanya ketidakseimbangan antara hukum pidana dengan hukum acara pidana yang dalam pelaksanaan putusannya terhadap perjudian merupakan kejahatan kesusilaan, untuk hal itu dapat mengakibatkan putusan batal demi hukum, sama halnya kalimat pada pasal 153 KUHAP yang pada dasarnya menyatakan persidangan terbuka untuk umum, kecuali mengenai perkara kesusilaan atau terdakwanya anak-anak. Terdapat kelanjutan dari ayat 4 (empat) KUHAP dijelaskan tidak terpenuhinya ayat (2) serta (3) KUHAP, mengakibatkan suatu putusan batal demi hukum.

\section{Kesimpulan}

Dari pemaparan dalam pembahasan di atas, maka dapat ditarik kesimpulan sebagai berikut: pertama, Hakekatnya perjudian merupakan tindak kejahatan terhadap kesusilaan, dan kesusilaan itu dipengaruhi oleh agama, kebudayaan, adat istiadat sebagaimana yang terdapat dalam masyarakat. Untuk itu terhadap kasus perjudian dalam persidangan, asas persidangan terbuka untuk umum sudahlah tepat dalam dunia peradilan, karena persidangan dapat dihadiri oleh umum, sehingga dapat lebih menjamin suatu obyektifitas peradilan dan tujuannya memberikan perlindungan terhadap hak-hak asasi terdakwa. Berbeda terhadap pengaturan pasal 153 ayat (3) KUHAP yang disebutkan bahwa sidang terbuka kecuali perkara mengenai kesusilaan dan terdakwanya anak-anak. Dalam hal ini telah jelas bahwa ketentuan dalam KUHP mengenai Buku II BAB XIV tentang Kejahatan terhadap Kesusilaan dan Buku III BAB VI tentang Pelanggaran Kesusilaan Berkaitan dengan asas tersebut yakni prinsip terbuka untuk umum, juga diterapkan pada kasus tindak pidana perjudian, dalam tindak pidana perjudian yang dalam pembahasannya dimasukkan dalam KUHP Pasal 303 Bab XIV Kejahatan terhadap Kesusilaan, maka seharusnya untuk proses pemeriksaan tindak perjudian sebagai kejahatan kesusilaan tertutup untuk umum, tidak ada pengecualian terhadap kasus perjudian sendiri, karena dalam kalimat "main judi di jalan umum atau di pinggir jalan umum atau di tempat yang dapat dikunjungi umum" merupakan tindak pidana kesusilaan yang menjadikan seseorang dapat 
melihatnya secara langsung yang kemudian dapat mengikuti dalam kegiatan perjudian itu sendiri. Sedangkan berkaitan dengan proses pemeriksaan juga seharusnya tertutup untuk umum, karena adanya beban pembuktian yang nantinya jika proses pemeriksaan itu terbuka untuk umum, akan dapat ditiru atau bahkan diterapkan oleh para pengunjung sidang, yang kemudian tindak perjudian semakin marak dan sulit untuk diberantas ataupun dihentikan kegiatannya.

Kedua, berkaitan dengan kasus tindak pidana perjudian para hakim maupun penuntut umum atau bahkan penasehat hukum khususnya yang menangani kasus tindak pidana perjudian telah mengabaikan ketentuan Pasal 153 ayat (3) KUHAP. Jika dikaitkan dengan putusan pengadilan maka peran hakim yang lalai atau lupa secara mutlak untuk menentukan suatu proses beracara itu terbuka ataukah tertutup untuk umum dalam perkara tindak pidana perjudian sehingga mengakibatkan putusan tersebut batal demi hukum.

\section{Daftar Bacaan}

\section{Buku}

Didik Endro Purwoleksono, Hukum Pidana (Airlangga University Press 2014).

Eman Sulaeman, Delik Perzinaan Dalam Pembaharuan Hukum Pidana di Indonesia (Walisongo Press 2008).

Fitroh Rohcayanto, Memperdagangkan Pengaruh?(Trading in Influence) Sebagai Tindak Pidana Korupsi (Universitas Airlangga 2018).

Hendik Bagus Sudiharto, Praktik Perjudian Legal Terselubung di Indonesia menurut Peraturan Perundang-undangan yang Berlaku (Universitas Airlangga 2015).

J.M. Van Bemmelen, Hukum Pidana Jilid I, II, III (Bina Cipta 1986).

Leden Marpaung, Kejahatan Terhadap Kesusilaan dan Masalah Prevensinya (Sinar Grafika 1996).

Oemar Seno Adji, Herziening Ganti Rugi Suap Perkembangan Delik (Erlangga 1984).

Peter Mahmud Marzuki, Penelitian Hukum Edisi Revisi (Preanada Group 2016).

Soka Adista Fajar Wirawan, Pelaksanaan Persidangan dalam Kasus Tindak Pidana Kesusilaan terkait dengan Penerapan Ketentuan Pasal 282 KUHP dan Pasal 
153 ayat 3 KUHAP (Departemen Pendidikan Nasional Universitas Brawijaya 2007).

\section{Jurnal}

Toetik Rahayuningsih, 'Kejahatan Kesusilaan dan Upaya Penanganannya (Studi pada Tingkat Penyidikan, Penuntutan, dan Pemeriksaan Pengadilan Surabaya' (1997) 31 Jurnal Universitas Airlangga.

Sri Hartini, Perbuatan Pidana Kesusilaan dalam Rancangan Undang-Undang KUHP (2004) 2 Jurnal Civics.

\section{Perundang-undangan}

Undang-undang Dasar Negara Republik Indonesia 1945.

Undang-Undang Nomor 1 Tahun 1946 tentang Peraturan Hukum Pidana Untuk Seluruh Wilayah Republik Indonesia jo. Undang-undang Nomor 73 Tahun 1958 tentang Menyatakan Berlakunya Undang-undang Nomor 1 Tahun 1946 Republik Indonesia tentang Peraturan Hukum Pidana untuk Wilayah Indonesia dan Mengubah Kitab Undang-undang Hukum Pidana (Lembaran Negara Republik Indonesia Tahun 1958 Nomor 127, Tambahan Lembaran Negara Republik Indonesia Nomor 1660).

Undang-Undang Nomor 8 Tahun 1981 tentang Hukum Acara Pidana. (Lembaran Negara Republik Indonesia Tahun 1981 Nomor 76, Tambahan Lembaran Negara Republik Indonesia Nomor 3209, untuk selanjutnya disebut KUHAP).

Undang-Undang Nomor 7 Tahun 1974 tentang Penertiban Perjudian (Lembaran Negara Tahun 1974 Nomor 54, Tambahan Lembaran Negara Nomor 3040).

HOW TO CITE: Renda Aranggraeni, 'Proses Pemeriksaan Perjudian sebagai Tindak Pidana Kesusilaan' (2019) Vol. 2 No. 5 Jurist-Diction. 
--halaman ini sengaja dibiarkan kosong-- 